\title{
Design and Synthesis of a Bimodal Target-Specific Contrast Agent for Angiogenesis
}

\author{
Anouk Dirksen, ${ }^{a}$ Sander Langereis, ${ }^{a}$ Bas F. M. de Waal, ${ }^{a}$ Marcel H. \\ P. van Genderen, ${ }^{a}$ E. W. Meijer, ${ }^{a,{ }^{*}}$ Quido G. de Lussanet, ${ }^{b}$ and \\ Tilman M. Hackeng ${ }^{\mathrm{c},}$
}

\begin{abstract}
${ }^{a}$ Laboratory of Macromolecular and Organic Chemistry, Eindhoven University of Technology, P. O. Box 513, 5600 MB Eindhoven, The Netherlands; ${ }^{b}$ Department of Radiology, Maastricht University Hospital, P. O. Box 5800, 6202 AZ Maastricht, the Netherlands ${ }^{c}$ Cardiovascular Research Institute Maastricht (CARIM), University of Maastricht, P. O. Box 616, 6229 ER Maastricht, the Netherlands.
\end{abstract}

E.W.Meijer@tue.nl andT.Hackeng@bioch.unimaas.nl

Received Date (will be automatically inserted after manuscript is accepted)

Solvents and Starting Materials. Unless stated otherwise, all reagents and solvents were purchased from commercial sources and used without any further purification.

Instrumentation. ${ }^{1} \mathrm{H}$ NMR and ${ }^{13} \mathrm{C}$ NMR spectra were recorded at $298 \mathrm{~K}$ on a Varian Unity Inova $500 \mathrm{MHz}$ spectrometer at 499.86 and $125.70 \mathrm{MHz}$, respectively. Chemical shifts $(\delta)$ are given in parts per million (ppm). Reversed phase high pressure liquid chromatography (RP HPLC) was performed on a Varian Pro Star HPLC system coupled to a UV-Vis detector probing at $214 \mathrm{~nm}$ using a $\mathrm{Vydac}^{\mathrm{TM}}$ protein \& peptide $\mathrm{C} 18$ column. Electrospray ionization mass spectrometry (ES-MS) was performed on a Perkin Elmer PE SCIEX Turbo Ionspray. To determine $T_{1}$ and $T_{2}$ relaxation times, a 2Dmixed dual echo sequence was performed (voxel size $10 \times 10 \times 8 \mathrm{~mm}$ ). The gadolinium content was determined by means of inductively coupled plasma atomic emission spectroscopy (ICP-AES) on a Leeman Labs Echelle spectrometer.

\section{Synthesis:}

NAcC(Acm)NGRC(Acm)GGMPAL (1). Manual solid phase peptide synthesis (SPPS) using the in situ neutralization/2-(1H-benzotriazol-1-yl)-1,1,3,3-tetramethyluronium hexafluorophosphate (HBTU) activation procedure for Boc chemistry on an MBHA resin, as described earlier by Schnölzer et al., ${ }^{1}$ was applied to synthesize a peptide containing the target-specific NGR sequence and a C-terminal thioester. ES-MS calcd. for $\mathrm{C}_{39} \mathrm{H}_{67} \mathrm{~N}_{14} \mathrm{O}_{14} \mathrm{~S}_{3}\left([\mathrm{M}+\mathrm{H}]^{+}\right)$: 1050.4 , found 1050.2 .

C-DTPA (2). The cysteine-functionalized DTPA synthon 2 was synthesized according to a literature procedure. ${ }^{2}$

NAcC(Acm)NGRC(Acm)GGC-DTPA (3). $30.6 \mathrm{mg}(0.029 \mathrm{mmol})$ of 1 and 1.5 equivalents $(24.7 \mathrm{mg}, 0.043 \mathrm{mmol})$ of 2 were dissolved in $1 \mathrm{~mL}$ of $6 \mathrm{M}$ Guanidine, $0.07 \mathrm{M}$ Tris (aq). To this solution $20 \mu \mathrm{L}(2 v-\%)$ of thiophenol and $20 \mu \mathrm{L}(2 v-\%)$ of benzyl mercaptan were added. The $\mathrm{pH}$ was adjusted to $\mathrm{pH} 7.5$ by the addition of small aliquots of $0.5 \mathrm{M} \mathrm{NaOH}(\mathrm{aq})$. The reaction was continued for 2 hours at $37{ }^{\circ} \mathrm{C}$. The reaction mixture was filtered and the product was purified employing preparative RP HPLC over a C18 column (gradient: $0-22 \% \mathrm{MeCN}_{\text {in }} \mathrm{H}_{2} \mathrm{O}, 0.1 \%$ TFA in 90 minutes). Freeze drying rendered $28.2 \mathrm{mg}(0.020 \mathrm{mmol}, 69.3 \%)$ of $\mathbf{3}$ as a fluffy white powder: ES-MS calcd. for $\mathrm{C}_{51} \mathrm{H}_{86} \mathrm{~N}_{18} \mathrm{O}_{22} \mathrm{~S}_{3}\left([\mathrm{M}+\mathrm{H}]^{+}\right): 1399.5$, found 1399.4 .

(1) Schnölzer, M.; Alewood, P.; Jones, A.; Alewood, D.; Kent, S. B. H. Int. J. Peptide Protein Res. 1992, 40, 180.

(2) Tolbert, J. T.; Wong, C. -H. J. Am. Chem. Soc. 2000, 122, 5421. 
NAcC(Acm)NGRC(Acm)GGC(OG488)-DTPA (4). $25.8 \mathrm{mg}(0.018 \mathrm{mmol})$ of 3 was dissolved in $1 \mathrm{~mL} 0.1 \mathrm{M}$ Tris (aq, $\mathrm{pH}$ 6.92). The $\mathrm{pH}$ of the solution was adjusted to $\mathrm{pH} 6.5$ by the addition of small aliquots of $0.5 \mathrm{M} \mathrm{NaOH}(\mathrm{aq})$ and subsequently added to $6.7 \mathrm{mg}(0.014 \mathrm{mmol})$ of malOG488. The reaction mixture was shaken until all malOG488 dissolved and the reaction was continued for 2 hours at room temperature. The reaction was monitored employing reversed phase HPLC over a $\mathrm{CD} 18$ column (gradient: $0-60 \% \mathrm{MeCN}$ in $\mathrm{H}_{2} \mathrm{O}, 0.1 \%$ TFA in 30 minutes) and showed that the reaction went to completion. The reaction mixture was used for the next reaction step without any purification. ES-MS calcd. for $\mathrm{C}_{75} \mathrm{H}_{97} \mathrm{~F}_{2} \mathrm{~N}_{19} \mathrm{O}_{29} \mathrm{~S}_{3}\left([\mathrm{M}+\mathrm{H}]^{+}\right)$: 1862.6, found 1862.8 .

NAc-cNGR-GGC(OG488)-DTPA (5). The reaction mixture was diluted $\sim 30$ times by adding $27 \mathrm{~mL}$ of $0.1 \mathrm{M}$ Tris (aq, $\mathrm{pH}$ 6.92 ) and $3 \mathrm{~mL}$ (i.e. $10 v-\%$ ) of acetic acid. Subsequently, $3.72 \mathrm{~mL}$ of a solution of $5 \mathrm{mM} \mathrm{I}_{2}$ in $\mathrm{MeOH}\left(0.018 \mathrm{mmol}\right.$ of $\left.\mathrm{I}_{2}\right)$ were added and the reaction was continued for 1 hour at room temperature. The product was purified employing preparative RP HPLC over a CD18 column (gradient: $0-18 \% \mathrm{MeCN}$ in $\mathrm{H}_{2} \mathrm{O}, 0.1 \%$ TFA in 5 minutes, then $18-36 \% \mathrm{MeCN}^{2} \mathrm{H}_{2} \mathrm{O}$, $0.1 \%$ TFA in 90 minutes). After freeze drying $17.9 \mathrm{mg}(0.010 \mathrm{mmol}, 71.4 \%)$ of $\mathbf{5}$ was obtained as an orange-colored fluffy powder. ES-MS calcd. for $\mathrm{C}_{69} \mathrm{H}_{85} \mathrm{~F}_{2} \mathrm{~N}_{17} \mathrm{O}_{27} \mathrm{~S}_{3}\left([\mathrm{M}+\mathrm{H}]^{+}\right)$: 1718.5, found 1718.7.

NAc-cNGR-GGC(OG488)-Gd(III)DTPA (6). $17 \mathrm{mg}(0.010 \mathrm{mmol})$ of 5 was dissolved in $10 \mathrm{~mL}$ of $\mathrm{H}_{2} \mathrm{O}$. The pH was adjusted to $\mathrm{pH} 7$ by adding small aliquots of $0.5 \% \mathrm{NH}_{4} \mathrm{OH}$ (aq). To this solution was added $1 \mathrm{~mL}$ of a $10 \mathrm{mM}$ solution $\mathrm{GdCl}_{3}$ in $\mathrm{H}_{2} \mathrm{O}$ (1 equivalent, $0.010 \mathrm{mmol}$ ). This was done in a stepwise manner and followed with ES-MS to ensure full complexation, avoiding the addition of an excess of $\mathrm{GdCl}_{3}$. Freeze drying rendered $\mathbf{6}$ as an orange powder. ES-MS calcd. for $\mathrm{C}_{69} \mathrm{H}_{82} \mathrm{~F}_{2} \mathrm{GdN}_{17} \mathrm{O}_{27} \mathrm{~S}_{3}\left([\mathrm{M}+\mathrm{H}]^{+}\right)$: 1873.4 , found 1873.7. ICP-AES gadolinium content: $94 \%$.

Relaxivity measurements of 6. For the relaxivity measurements a dilution series of 6 was prepared in $\mathrm{H}_{2} \mathrm{O}: 0.8 \mathrm{mM}, 0.6$ $\mathrm{mM}, 0.4 \mathrm{mM}, 0.2 \mathrm{mM}, 0.1 \mathrm{mM}$, and $0.05 \mathrm{mM}$. Each sample has a volume of $2 \mathrm{~mL}$. For each concentration the relaxation times were determined, giving a good linear fit $\left(\mathrm{R}^{2}>0.999\right)$ to the equation $\left(1 / T_{l, 2}\right)_{\text {observed }}=\left(1 / T_{1,2}\right)_{\text {diamagnetic }}+r_{l, 2}[\mathrm{Gd}(\mathrm{III})]$. The relaxivities were calculated in terms of the actual gadolinium content as determined with ICP-AES.

HPLC traces of 1, 2, 3, 4, and 5. HPLC traces were obtained through RP HPLC using an analytical C18 column for separation and UV-Vis detection probing at $214 \mathrm{~nm}$. A gradient was applied of $0-60 \% \mathrm{MeCN}$ in $\mathrm{H}_{2} \mathrm{O}, 0.1 \%$ TFA in 30 minutes). For Comparison: left: HPLC traces of 1, 2, and 3; right: HPLC traces of 3, 4, and $\mathbf{5}$.
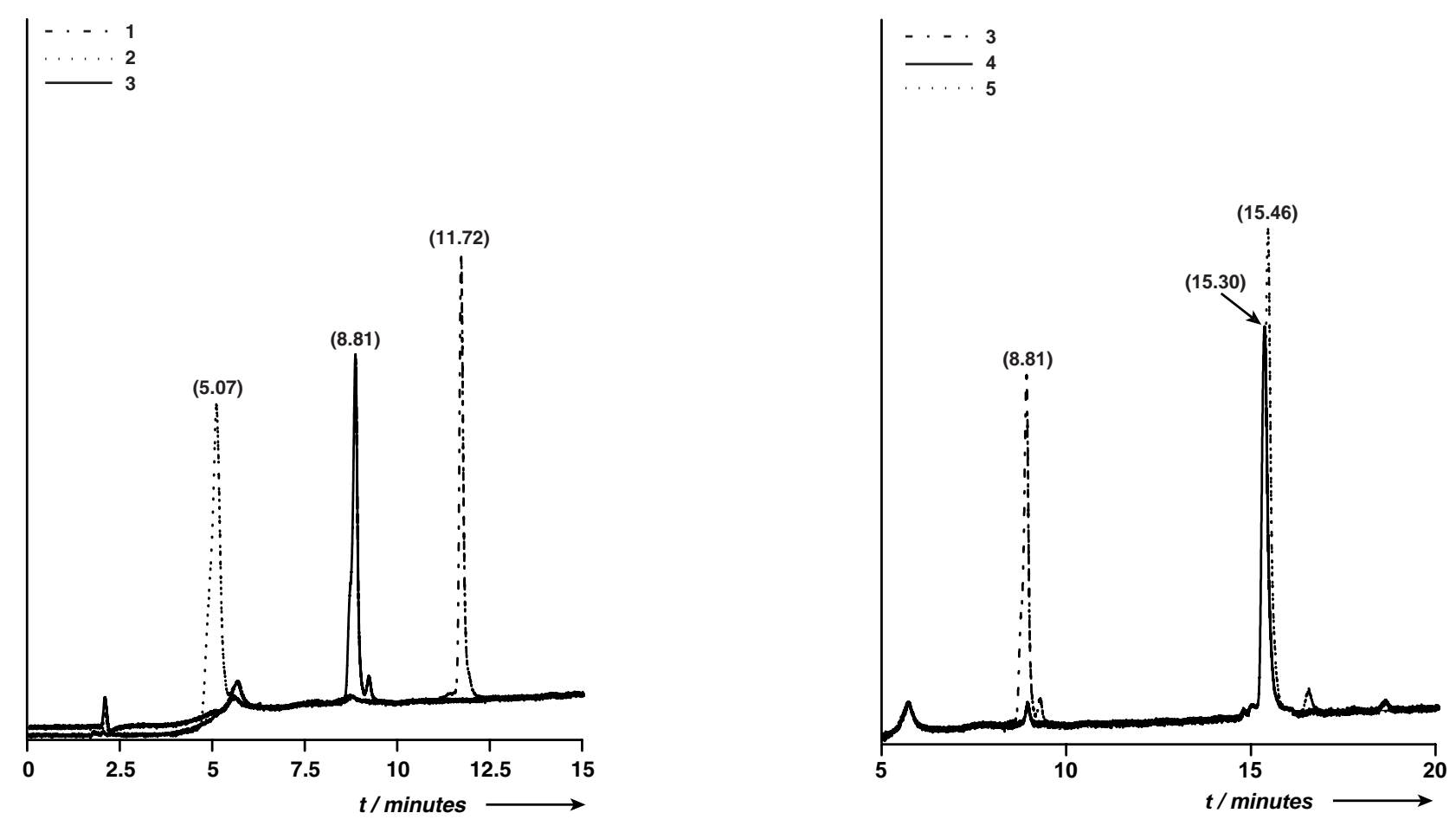